\title{
"Global alternatives, regional stability and common causes": the international politics of the Shanghai Cooperation Organization and its relationship to the West.
}

\author{
Dr Stephen Aris, Center for Security Studies, ETH Zurich \\ Dr Aglaya Snetkov, Center for Security Studies, ETH Zurich
}

\begin{abstract}
Two scholars of the international relations of Eurasia consider the "geopolitical identity" of the Shanghai Cooperation Organization (SCO). They firstly outline that most of the existing analysis and comment on the SCO assumes its raison d'etre to be countering the "West" in Eurasia and beyond, and suggest that this narrow perspective does not afford the SCO enough agency, which leads to a distorted picture of the variety of SCO discourse and behavior. Secondly, they outline a framework, based on a combination of the literatures on Critical Geopolitics and identity-focused International Relations, for examining the "geopolitical identity" of the SCO. The article then traces the SCO's geopolitical discourse on its own collective identity, its relationship to the West in wider international affairs, Eurasia and in areas in which it seeks active collaboration with the West. It is argued that while in many contexts the SCO's geopolitical discourse is indeed built upon a Self-Other dynamic that contrasts their common positions on certain international issues against those of the West, in others it identifies similarity to the West and suggests a larger in-group between itself and the West.
\end{abstract}




\section{Introduction}

The Shanghai Cooperation Organization (SCO) has been gaining increasing international visibility since its establishment in 2001. Its membership of Russia, China, and four post-Soviet Central Asian Republics (Kazakhstan, Kyrgyzstan, Tajikistan and Uzbekistan), as well as Afghanistan, India, Iran, Mongolia and Pakistan as observer states, has led it to be considered a significant actor within the wider Eurasian space. In spite of its membership and predominant focus on Eurasia, the majority of characterizations of the SCO - in both the existing literature and in the media - are that it is predominately defined by a desire to counter the West. ${ }^{1}$

While there is a growing literature on the SCO, little attention has been paid to the SCO's geopolitical discourse, or "geopolitical imagination" (Agnew, 2003). ${ }^{2}$ Hence, to a certain extent, the depiction of the SCO as counterpoised to the West is based on a one-sided reading of its relevance to the West's "geopolitical imagination". Further, this view is based on the assumptions of a traditional geopolitical perspective, which Agnew refers to as the "modern geopolitical imagination" (Agnew, 2003), whereby "states are in an unremitting competition with one another for primacy" (Agnew, 2010a, p. 572). Due to its membership, many commentators have deduced that it is logical that the SCO must be defined by a desire to challenge the West. In the last decade, China has been characterized as an "emerging superpower", whose rise is likely to alter the prevailing global balance-of-power. During the same period, Russia has expressed an ambition to be recognized as a "great power" (Neumann, 2008; Tsygankov, 2005; Adomeit, 1995) and is considered a state with a long history of competition with the West. Hence, it has be concluded that an organization containing these two actors must be driven by an agenda of undermining the prevailing hegemonic position of the US, and the West at large, within the international system.

To examine the SCO's various spatial and normative identity constructions, and the role that its perception of the "West" plays to this end, this article draws on the literatures of Self/Other identity relationships (Morozov and Rumelili, 2012; Prozorov, 2012; Epstein, 2011; Suzuki, 2007; Neumann, 1999; Campbell, 1998; Neumann, 1996), critical geopolitics (Dalby, 2008; Paasi, 2006; Agnew, 2003; Ó Tuathail, 1996; Ó Tuathail, and Agnew, 1992; Dalby, 1991) and the emerging literature on the interjection between regional studies in political geography

\footnotetext{
${ }^{1}$ The term "Western" has come under increasing interrogation in recent years, particularly with regard to the discussion about the division between Western and non-Western IR. In this paper, however, the question of the West is approached from the point of view of the existing literature on the SCO that itself tends to labels this particular regional organisation as "anti-Western" as will be outlined in the review literature. Therefore the point of departure is to examine whether this is indeed the way in which the SCO itself constructs itself and its Others. For a greater discussion of the "West" as opposed to the "non-West" see: Acharya, 2011; Hutchings, 2011; Acharya and Buzan, 2010; Tickner and Waever, 2009; Bilgin, 2008; Tickner, 2003.

${ }^{2}$ Ambrosio $(2009 ; 2008)$ has examined the norms and discourse articulated by the SCO in relation to democracy.
} 
and contemporary geopolitics (Popescu, 2008; Prozorov, 2007; Glassman, 2005; Toal, 2003; Kaplan and Hakly, 2002). It traces how the SCO's geopolitical discourse, or identity, on international/regional affairs is built upon a Self-Other dynamic with regard to the West. In this paper, Self/Other constructs are seen as composed of three broad types, the discourse on the Self from within, the Other as similar/different, and the Other as an opposite, while acknowledging that in practice these analytical divisions are blurred. It is argued that with regard to certain spaces and issues the SCO seeks to construct an in-group among its members by contrasting their common positions against those of the West. However, in others it seeks to build a larger in-group with the West.

This paper thus bears out the view that the West plays the role of an important counterpoint for the SCO and that it often defines itself against the West. However, this is the case only in some respects, and in some spaces. In other respects and spaces the West does not play such a role, and indeed is sometimes constructed as a similar, even collaborative, Other. Therefore, it is suggested that a more nuanced understanding of the geopolitical identity of the $\mathrm{SCO}$ is required than that of the prevailing popular characterizations. To this end, the SCO should be allowed greater space and agency to define its own geopolitical identity instead of being considered only in relation to the West.

This article firstly surveys the current literature on the SCO, secondly it outlines its basic theoretical assumptions about identity and geopolitics, and thirdly, traces the SCO's geopolitical discourse on its own identity, and that of its relationship to the West in terms of both Eurasia and the wider international system.

\section{The SCO and Its Geopolitical Discourses}

Ever since its creation in 2001, the SCO has predominately been depicted as an anti-Western grouping, created in order to counter-balance the West's (and particularly the US) influence in Eurasia and as a Russian-Chinese driven anti-Western bloc in the wider global space (Ferguson, 2012; Naarajärvi, 2012; Carroll, 2011; Wilhelmsen and Flikke, 2011). As outlined in the introduction, this perspective tends to be shaped by a traditional reading of "geopolitics", and the assumption that states inevitably compete for influence, status and control over resources $v i s-\grave{a}$-vis one another and in terms of their hierarchical position within the international system. As Agnew notes "[f]rom this viewpoint, achieving high rates of economic growth will automatically translate into an urge for great power at others' expense and the anarchy of the world beyond state borders makes this task inevitable" (Agnew 2010a, p.572). With the Chinese 
"economic miracle" continuing apace, and Russia's openly outlining its desire for "great power" status, a lot of analysis of the SCO has taken this perspective. This is perhaps unsurprising given that one of founding fathers of "geopolitics" as a school of thought, Halford Mackinder, made the case for such a perspective by arguing that the geographical area which is roughly proximate to that of the membership of the SCO, represents the "heartland" of world geopolitics and the "pivot" of world history (Mackinder, 1904). ${ }^{3}$

The existing literature varies in its depiction of the geopolitical orientation of the SCO as an actor, and the primacy, and nature, of its perceptions of and relationship to the West. Some analysts have viewed the SCO as nothing more than a vehicle to counter the "West", be that the United States (US), North Atlantic Treaty Organization (NATO), European Union (EU). ${ }^{4}$ Other scholars have not characterized the SCO as solely defined by an anti-Western purpose, but have emphasized the divergence and clash between the values of the SCO and the West. ${ }^{5}$ While others have set out to examine the SCO in terms of its own regional context, emphasizing that its relationship to the West is not integral, but have nonetheless sought to address questions about the SCO's relationship with the West (Aris, 2009; de Haas, 2008; Gene, 2008). Indeed, the propensity of the current literature to focus on the SCO as driven and defined by antiWesternism has been noted by several scholars. ${ }^{6}$ The coverage of the SCO in the popular media has been even more explicit in depicting it as centered on countering the West. ${ }^{7}$

Whilst, the image of the SCO as an aggressive anti-Western actor has softened somewhat in recent years, the remnants of these underlying assumptions about the SCO remain. This is illustrated by accounts of the SCO's proclaimed focus on playing a larger role in Afghanistan as driven by an attempt to counter-balance NATO in Afghanistan (Fiacconi, 2012), rather than as a bid to deal with a common regional security dilemma. Indeed, this tendency to consider the SCO as primarily an anti-Western bloc and not a multilateral framework focused on issues within its own region, is consistent with broader trends that linger in international relations literature and policy analysis. Such analysis tends to interpret non-Western actors' identity constructions and central foci as primarily framed through the binary of their

\footnotetext{
${ }^{3}$ For an analysis of the framing of Central Asia in Western academia, including the role of Mackinder's "Eurasian Heartland" thesis in this, see Heathershaw and Mergoran, 2011; Sengupta, 2009; Heathershaw, 2007; Megoran, 2004.

${ }^{4}$ Cohen (2006) states that the "SCO primarily serves as a geopolitical counterweight to the United States". While a US Senator proclaimed that "SCO is "the most dangerous organisation Americans have never heard of " and ""a potential Warsaw Pact" (Brownback, 2006) .

${ }^{5}$ Ambrosio outlines that the SCO "represents a formidable challenge to the ideas of universal democracy and human rights through its de facto legitimisation of authoritarianism and by establishing itself as a counterweight to external democratic norms" (Ambrosio, 2008, p. 1322). While, Bailes and Dunay (2007, p. 13) noted, "up to very recently, analytical writing about the SCO ....[has] liked to stress how far away the Organisation actually is from European traditions and norms in its way of dismissing human rights concerns and forbidding mutual 'interference in internal affairs"”.

${ }^{6}$ Hanova argues that "Russian and Chinese interests in the SCO are often reduced to a common objective of anti-Americanism" (2009, p. 80). Troitsky states the "Western assessments sometimes view the SCO as increasingly becoming a mechanism to oust the USA and its Western allies from Central Asia, and thus to threaten Western security interests" (Troitskii, 2007).

${ }^{7}$ A BBC (2012) report notes it is "widely viewed as a countermeasure to curb the influence of Western alliances, such as Nato"; Sky News 2008) outlined that "the alliance was established in 2001 to counter NATO influence in the Central Asian region"; Tony Halpin writing in The Times noted that it "increasingly regarded by Moscow and Beijing as a counterweight to US global influence". 
relationship with the West, or in other words a "non-Western/Western" Self/Other dynamic (Agathangelou and Ling 2009; Hobson 2007; Barkawi and Laffey 2006).

This paper is focused on the SCO's discourse and attempts to construct geopolitical space, and to this end it treats the SCO's geopolitical discourse as a coherent discourse for analytical purposes. However, like all multilateral organizations, the SCO cannot claim to present a fully coherent and collective representation of its member-states geopolitical perspective and interests. Indeed, as with all collective groupings, the SCO is the subject of competing and divergence of voices among its membership. These areas of contention among the SCO members have centered on whether it should primarily focus on security or economics (see Aris, 2011, pp. 78-83; Bailes and Dunay, 2007, p. 16-17; Oldberg, 2007, p. 28), the depth of integration (see Aris 2011, pp.175-7; Bailes and Dunay, 2007; Oldberg, 2007, p. 35; Troitskii 2007, p.34), and the potential expansion of its membership and the long-term identity of the organization (see Aris 2011, pp.164-170; Bailes and Dunay, 2007, p. 19; Makhmudov, 2007; Portyakov, 2007).

Also, the SCO faces a number of challenges. The effectiveness of the SCO as a model for multilateral cooperation has often by questioned due to some of the very concepts and principles it espouses as part of its geopolitical discourse, namely non-intervention in domestic affairs. This is exacerbated by the reluctance of some of the member states' regimes to participate in any form of cooperation, let alone integration, which may threaten their own sovereign control over all internal policy matters (Aris, 2011; Allison, 2008; Allison, 2004). In addition, scholars have highlighted a degree of distrust between some of its members (Bond and Koch, 2010; Allison, 2004). Against this background, the effectiveness of the SCO as a force for regional security management has been questioned by both Western (Bond and Kuch, 2010; McDermott, 2010; Melvin, 2010; Weitz, 2010) and regional analysts (Morozov, 2009; Portyakov, 2007; Zhao, 2006). This is due to the SCO's focus on the principle of non-intervention and the lack of both its capacity and willingness to act as a collective multilateral actor. The SCO's model of regional cooperation, while strongly limited in terms of its effectiveness to act as an agent for regional security management, is to a large degree consistent with its discursive geopolitical vision about what should define the norms, values and standards of international relations.

Broadly speaking there is less contestation concerning the SCO's conception of geopolitics than in other areas of its agenda. The primary dividing line on geopolitical matters has been on the degree to which the SCO should represent itself as a counter-Western actor within the international system, with reservations expressed about such a focus among the more Western-orientated Central Asian Republics (Aris, 2011, pp. 146-8; Maksutov, 2006, p. 9). Notably, Kazakhstan is considered to be concerned that overt anti-Western rhetoric may impact on the increasingly investment in Kazakh energy resources by Western companies (Maksutov, 
2006, 9; Shaimergenov and Tusupbaeva, 2006). ${ }^{8}$ However, Moscow's and, especially, Beijing's ${ }^{9}$ desire to keep the Central Asian member states engaged in the development of the SCO project has led both to refrain from pushing the other states into endorsing statements and positions that they strongly oppose, with the exception of the declaration on the RussianGeorgian War and during the Osh Riots (2010), both of which will be discussed below. ${ }^{10}$ In this way, the reservation of some of members about overt anti-Western comment restricts the scope for such discourse within the SCO and provides a check on excessive anti-Western rhetoric. Furthermore, all the members have at various times deemed the SCO to be a useful geopolitical tool in their own foreign policy. Thus, in spite of certain cases of divergences on particular incidents, there has been very little public disagreement with SCO geopolitical statements from its own membership and it has been able to put forward a relatively consistent and coherent geopolitical vision over the last decade.

\section{Analytical Framework}

To assess the SCO's geopolitical identity, and the significance of the West in this regard, this article adopts an interdisciplinary analytical framework, drawing on insights from both critical security studies and critical geopolitics scholars. ${ }^{11}$ These are utilized to examine the identity Self/Other construction of the SCO and its production of geopolitical discourses and practices.

As outlined by Müller, "adopting a constructivist perspective, critical geopolitics examines the very construction and social effects of geopolitical imaginations and geopolitical identities - the imaginary spatial positioning of people, regions, states and the shifting boundaries that accompany this positioning" (Müller, 2008, p.323). How actors define their geopolitical identities, often in relation to what is understood as lying within the "internal" space and its differentiation to the "external" space, also defines how they view the nature of the wider geopolitical space and their role, place and hierarchical position within it. By

\footnotetext{
${ }^{8}$ This dynamic is interpreted by many as part of the wider context of growing competition for energy resources in Kazakhstan, involving primarily Western, Russian and Chinese companies (Pannell, 2011; Marketos, 2009a; Wishnick, 2009).

${ }^{9}$ China's adoption of a soft power strategy towards the Central Asian Republics has been noted by many scholars, and is consider as aimed at "demystifying" the Chinese presence in the region and altering the prevailing negative perception of China within these states (Pannell, 2011; Aris, 2009; Pan, 2008). This also includes not being seen as a bully in pushing the Central Asian Republics into making statements that they do not wish to. Another dimension to this strategy is said to be gaining access to much-need energy resources from this region. Pannell argues that China's adoption of a "soft power" approach to Central Asia since 1991 is "a tale of increased administrative and military capacity, but perhaps more importantly on the other hand, is a matter of expanding economic and diplomatic influence and a good example of the flowering of China's soft approach to the application of power and the success of its diplomacy and commercial thrust. At the same time China has serious need for various resources, especially oil, and this too requires attention and analysis to assess its significance" (2011, p. 107/8). This increasing mutual-interest and interdependence (Pannell, 2011) in relation to the Central Asian Republics for material needs also encourages China not to act overly forcefully towards these states within the SCO. Hence, for example China is competing with Western energy firms for contracts in Kazakhstan, which in turn incentivizes Beijing not to push Astana into any statements it feels uncomfortable with regarding the West, in order to avoid unnecessarily pressurizing this relationship.

${ }^{10} \mathrm{It}$ is also arguable that there was some disagreement over the 2005 Astana Summit Declaration (see Shaimergenov and Tusupbaeva, 2006)

${ }^{11}$ Thus, it bridges the gap between critical geopolitics and critical security studies by putting forward an interdisciplinary analytical framework that draws on insights from both these fields of enquiry (also see Dalby, 2010a; 2010b; 2008; Mamadouh and Dijink, 2006). 
extension, this colors how they view other actors and spaces, which are interpreted in relation to the said actor's reading of how they fit within the international system and in turn reflect their "national interests and identities" (Agnew, 2010a, p. 570).

This tendency to view Others in the world through your own - Self - geopolitical imaginary and identity, often leads to misrepresentation of the perspective of the Other. Indeed, Self-defined assumptions frame an actor's reading of the Other according to a filter of predetermined biases. Accordingly, this limits the space for the agency of that Other. Such tendencies underlie the criticism of much of Western IR and geopolitical analysis of the nonWestern world. Scholars have criticized the Eurocentric, or Westerncentric, viewpoints on the non-West, which impose Western assumptions and conceptions onto other contexts in which they do not have the same significance, and deny non-Western actors agency by only viewing them in terms of their relevance to Western interests (Hobson, 2012; Agathangelou and Ling, 2009; Bilgin, 2008; Sidaway, 2008; Hobson, 2007; Barkawi and Laffey, 2006; Robinson, 2003). For example, as noted by Agnew with reference to Western analysis of China, "it is foreign commentators who are especially prone to interpret China's geopolitical position exclusively in terms of Western conventional wisdom" (Agnew, 2010a, p. 572). Taking this into account, this paper seeks to examine the SCO's discourse on geopolitics from this organization's perspective and discourses, rather than simply by imposing objective models or principles from outside.

Starting from this "critical geopolitics" perspective, this article draws on the synergies between the assumptions of "critical geopolitics" and "constructivist IR" approaches, in order to outline a framework for examining the Self-Other dynamic in the SCO's geopolitical discourse vis-à-vis the West. As Mamadouha and Dijkinka note "critical geopolitics relates more clearly to constructivist approaches in international relations (IR), studies focusing on the formation of international and security identities and strategic culture" (Mamadouha and Dijkinka, 2006, p. 355). Post-positivist IR scholars assert that identity is the product of an actor's understanding of Self and Other, as well as the normative structures of the context in which it functions. ${ }^{12}$ In other words, identity is constructed by an actor's perceptions of its own identity and that of the outside world, including Other actors. The notion of the Other is "an epistemological necessity in the definition of the self: the very capacity to experience a self is contingent upon otherness; it is in dialogue with others that the self is shaped" (Honneland, 1998, p. 281). An actor's perception of the Other(s) thus enables it to distinguish itself from

\footnotetext{
${ }^{12}$ For an up-to-date summary of the debate on identity and the Self/Other dynamics see Morozov and Rumelili, 2012, Prozorov, 2012 and Epstein, 2011. 
Others, by identifying differences between other actors and itself, and also by constructing its relationships with these Others within its perceived context (Snetkov, 2010).

However, as opposed to the conception of identity found in more poststructuralist literature (e.g. Mouffe, 2000; Campbell, 1998), this article considers that the Self-Other dynamic is not inevitably formed around an antagonistic relationship between the Self and the Other. While, an actor constructs its identity in relation to what it perceives its Others to be, the nature and identity of this Other is not fixed. Thus, a variety of different constructions of the Other and its relationship to the Self are possible. As Hansen (2006, p. 38) argues "less-thanradical Others" are commonplace, and as noted by Hopf, "identities are always relational, but only sometimes oppositional” (Hopf, 2002, p. 7).

Indeed, this article concurs with the scholars that argue that a range of possible constructions of the Other exist (Herschinger, 2012, p. 73; Morozov and Rumelili, 2012; Buzan and Waever, 2009, p. 262; Hansen, 2006; Campbell, 1998): These include an oppositional and antagonistic Other, seen in direct contrast to the Self; an Other which is seen as different but not antagonistic to the Self; or an Other with which the Self sees similarity and with which it can construct a common in-group identity (Hansen, 2006). Taking this into account, as suggested by Hansen, there is a need for an analytical framework that allows not only for the study of "a radically different and threatening Other", but which also accounts "for degrees of difference and Otherness" (2006, p. 38).

Furthermore, and given the article's focus on a multilateral actor, the importance of collective identity formation that is not automatically centered on the process of Othering is asserted, particularly when analyzing processes of identity construction of regional organizations. Indeed, drawing on the work of Krasner (1999), Abizadeh makes the distinction between two forms of sovereignty and self/other dynamics: sovereignty/control within a particular territorial space and sovereignty/control of external borders in relation to other actors in the international system. Whilst the latter does indeed delineate spatially between Us and Them, the former is centered on sovereignty/identity building drawn from within a particular space that does not per se need to be constructed on an explicit Self/Other dynamic (Abizadeh, 2005, pp. 49-50).

This is an aspect of collective identity building that is now an accepted feature in the study of the EU and its identity building processes, ${ }^{13}$ and is increasingly also being recognized with regard to the study of the Association of South East Asian Nations (ASEAN) via the notion

\footnotetext{
${ }^{13}$ For a more extensive discussion on this see Morozov and Rumelili, 2012; Prozorov, 2011; Manners, 2006; Diez, 2004; 2005; Rumelili, 2004; Waever, 1995.
} 
of the "ASEAN-way" (Acharya, 2001). However, analysis of the SCO has continued to downplay this aspect of collective identity building within the SCO itself, and has instead, as noted above, emphasized its function as a counterbalance to the West. Against this background, this article argues that in contrast to a lot of existing analysis of "non-Western" regional organizations, it is necessary to recognize the agency of non-Western actors. Firstly, in terms of their capacity to construct their own view and position towards the Other. Secondly, in their ability to construct their collective identity according to local dynamics that are not directly constructed through their relationship with the West.

Finally, this article asserts that an actor does not have a single fixed identity, including in terms of a Self/Other dynamic. Rather, identity construction functions across a wide-range of spatial, temporal and issue contexts, and are not necessarily the same in all. In this respect, this paper rejects the more mainstream definition of identity (Wendt, 1992) as "essentially selfsameness, or what makes an object unique" and "involves assumptions about stability over time - a self or object is assumed to have a stable, unchangeable essence or core" (Ortmann, 2008, p. 51). Instead, identity constructions are on-going processes and in constant evolution, emphasizing "the fluidity and contextual nature of identities" (Abdelal et al, 2006, p. 697). Whereas, much of the current literature on geopolitical discourses and identity constructions focus on a single strand or dimension of the Self/Other dynamic, this perspective suggests that is necessary to take into account the variety of spatial discourses and positionalities that exist in different contexts and on different issues and aspects of relationships. As noted by Morozov and Rumelili "positive and negative representations of the Other can coexist and be projected upon different aspects of the Other's identity" (Morozov and Rumelili, 2012, p. 31) Therefore, multiple strands of identity constructions and processes of othering are possible within the same corpus of geopolitical discourse. Hence, we proceed from "an understanding of the degree to which all states ..... must necessarily adjust in practice to a world politics in constant evolution and not just of their making" (Agnew, 2010a, p. 575).

Against this background, the question of whether or not the SCO is an anti-Western organization is not an easy one to answer, nor is it easy to characterize the nature of the Self/Other dynamic between the SCO and the West as based on a single identity construction. In practice, as outlined below, the answer varies depending on which particular strand of the SCO's geopolitical discourse one examines. Taking this into account, the next section surveys the SCO's geopolitical discourse with regard to its Self, and the West as its primary Other, across the full range of spatial and issue-areas in which this Self-Other dynamic is active. 


\section{The SCO's geopolitical discourses ${ }^{14}$ through the Self/Other dynamic}

A collective identity: the formation of an in-group among the SCO members

In contrast to the majority of characterizations of its identity in existing analysis, officials within the SCO seek to communicate that the SCO is primarily concerned with the building of an ingroup among its member-states. The SCO Charter states that "the main goals and tasks of SCO are: to strengthen mutual trust, friendship and good neighborliness between the member States', including the "search of common positions on foreign policy issues of mutual interest, including issues arising within international organizations and international fora" and that it is "not directed against other States and international organizations" (Charter of the Shanghai Cooperation Organization 2002). Highlighting this aim, Vladimir Putin outlined in 2006 that "[at a time] when statements about ostensibly insuperable cultural and civilizational divides between states are reviving, the Organization [SCO] offers an excellent example of an equal rights partnership in Eurasia" (Putin, 2006). In 2007, the SCO member states signed a "Treaty on Long-Term Good-Neighborliness, Friendship and Cooperation Between the Member States of the Shanghai Cooperation Organization", which as well as emphasizing the coordination among its members, also sought to reemphasize that the SCO is "not be directed against any States or organizations, and that the Contracting Parties shall follow the principle of openness to the other countries of the world" (Treaty on Long-Term Good-Neighbourliness, Friendship and Cooperation Between the Member States of the Shanghai Cooperation Organization, 2007).

It has been argued that the basis for such an intra-regional focus has grown since the second half of the 2000s. Although the SCO's record of implementing its economic agenda is patchy, its member states have at least begun to realize the potential mutual economic benefits from a closer and more coordinated relationship (Aris 2011; Portyakov 2007; Chung 2006). In this respect, an important dynamic has been the growth in Chinese, and to a much lesser extent Russian, investment in the Central Asian Republics. This Chinese investment is seen as driven by its need for greater energy resources (Pannell, 2011; Marketos, 2009b; Sheives, 2006), while both Russia and China hope to establish their influence in the region in the face of growing competition from other external powers (Bailes and Dunay, 2007; Oldberg, 2007). From the Central Asian leaderships' perspective, their states are, to varying extents, dependent on foreign

\footnotetext{
${ }^{14}$ The main methods by which the SCO seeks to express its views on the international stage are by the issuing of statements with regard to international events, and more importantly the common declarations issued at the annual summit meetings of the Heads of State. 
investments, and such investment is considered as valuable for stabilizing their states and thus the security of their regimes, as long as it does not threaten their sovereign control over their national economy (Aris, 2011; Allison, 2004). In 2006 China offered $\$ 900$ million to SCO member states in the form of preferential buyer's credit for Chinese exports. While in the wake of the 2008 financial crisis, China made $\$ 10$ billion of loans available to support economic cooperation. Furthermore, both Moscow and Beijing are seen as the driving force behind the idea of creating an SCO "Energy Club", seen by many in the context of growing competition over access and the direction of energy pipelines (Frolenkov, 2008; Oldberg, 2007; Troitskii, 2007).

Hence, in recent years the emphasis on developing mutual economic interests and interdependence between the SCO member states has increased. For example, in relation to the burgeoning Chinese-Kazakhstan relationship on energy, which is seen as conditioned by a background of direct competition with the growing engagement of Western energy companies in Kazakhstan during recent years, ${ }^{15}$ Pannell notes that from a Chinese perspective this represents "a strategic as well as practical response to this growing demand and necessity for China's rapidly growing economy. It also serves to further intensify China's economic ties to Kazakhstan in such a way that creates mutual benefits but also some increased dependency" (Pannell, 2011, p. 111). Although, economic cooperation is mainly limited to energy and largescale infrastructural projects ${ }^{16}$ and predominately restricted in implementation by concerns over maintaining economic sovereignty ${ }^{17}$, it has nonetheless contributed to a Eurasian context which is, to at least some extent, more conducive to the development of intra-regional identity within the SCO.

As well as highlighting that it is focused on intra-regional matters, the SCO does express the aim of becoming a voice in wider international affairs. The 2006 SCO summit declaration outlines that the "SCO member states will continue to strengthen coordination and cooperation in international and regional affairs and take a common position on matters involving SCO's interests" (Declaration on the Fifth Anniversary of the Shanghai Cooperation Organization, 2006; Joint Communiqué of Meeting of the Council of the Heads of the Member States of the Shanghai Cooperation Organization, 2006). In relation to this, the SCO asserts that its views on international relations are primarily driven by dynamics from within its regional context and its

\footnotetext{
${ }^{15}$ For more on recent development in Kazakhstan's relationship with Western companies investments see Weitz, 2012 ; Kilner 2012

${ }^{16}$ Russia, and to a lesser extent the Central Asian Republics, seek to keep economic cooperation in the SCO limited to large-scale infrastructural projects, and are reluctant to engage in negotiations for creating an SCO free trade, which is seen as a long-term Chinese aim. From the Russian perspective, this reluctance is due to a fear that it will lose economic influence in the region in open competition with China, and thus prefers to keep micro-economic cooperation within the EurAsEC and Single Economic Space projects (Aris, 2011; Bailes and Dunay, 2007; Oldberg, 2007).

${ }^{17}$ The Central Asian Republics are concerned that if China is allowed too much access to their economies then they will overwhelmed by the size and competitive advantages of the Chinese economy. 
sense of Self, rather than being fundamentally defined by a competitive dynamic vis-à-vis the West.

The SCO's discourse on international affairs is therefore often directly related to the specifics of the Eurasian context and the interests of its member states. The SCO has thus proclaimed itself to be focused on responding to the problems dominating the region, such as what it has labeled as the "three evils" that have beset the region: terrorism, separatism and extremism (Shanghai Convention on Combating Terrorism, Separatism and Extremism, 2001). However, the SCO's inaction in response to a request for external assistance by the interim Kyrgyz government during the Osh riots in $2010^{18}$ has focused attention on the capacity of the SCO to intervene in regional security crises (Aris, 2012; Bond and Koch, 2010). Nonetheless, in its geopolitical discourse the SCO has continued to emphasize the importance of a focus on regional security, with its 2011 Astana summit declaration noting that "the tasks of fighting against terrorism, separatism and extremism remain the key priorities for the SCO (Astana Declaration of the 10th Anniversary of the Shanghai Cooperation Organisation, 2011).

According to a number of scholars, a shift in the approach to the "three evils" is evident between the early period after the formation of the SCO, in which it was primarily centered on countering the threat of extremist, separatist and opposition groups conducting terrorist operations, and the second half of the 2000s onwards, since when this remit has been expanded to include any dynamic seen as agitating against the existing regimes due to the experience of the "color revolutions" (Allison, 2008; Ambrosio, 2008; Lanteigne, 2006/7). The focus placed on addressing challenges within the region is often related to ensuring that this concentration on the Self is not undermined by the actions of extra-regional actors within Eurasia. This is reflected in its discourse on international affairs, which both seeks to signal that it is driven by a focus on its own region, but also that it considers interference by external actors within its own region as a geopolitical challenge; in particular the propensity of Western states to interfere in the domestic affairs of non-Western states. This approach is, however, not presented as automatically anti-Western. Indeed, as noted by the Russian Deputy Minister of Foreign Affairs, Alexei Borodavkin,

SCO does not operate to spite or suit someone. It advocates reinforcing security and stability, developing many-sided partnerships for the good of the peoples of our countries

\footnotetext{
${ }^{18}$ The city of Osh experienced large-scale violent rioting and looting between 11 and 14 June 2011. The violence is said to have occurred along multiple dividing lines: ethnic, in particular in the form of ethnic Kyrgyz attacking ethnic Uzbeks; political, with groups loyal to the ousted President Bakiyev and opposed to the interim government seeking to create chaos ahead of a nationwide referendum on a new constitution; criminal, organised criminal groups sought to capitalise on the ensuing chaos for their own purposes. The resultant violence cost many lives and led to widespread destruction of homes, businesses and infrastructure in and around the city, which highlighted that the interim government was not in control of events.
} 
and forming an institutional architecture of international relations based on mutual respect, due consideration for the interests of each other, and equal cooperation (Borodavkin, 2008).

The principle of "local" norms taking primacy in regional affairs in order to restrict global dynamics entering the region was also present in the SCO's response to the global financial crisis in 2008/9. The need to strengthen financial and economic mechanisms of regional cooperation has been outlined annually during the SCO Summits since 2009. As noted by the Chinese President Hu Jintao in June 2012 "[w]e should build the SCO into a driving force to boost regional economic development" (Xinhuanet, 2012). The subsequent proposals for the "establishment of a development bank, food security cooperation mechanism, energy club and seed banks, and for the promotion of trade and investment facilitation" (Xinhuanet, 2012) were intended to support regional actors in mediating global trends seen as negatively impacting on the region. At the same time, the SCO has sought to highlight that it considers wider international cooperation on this issue as imperative, ${ }^{19}$ as well as maintaining a specific regional approach aimed at shielding the region from adverse trends beyond it.

Similarly, discussions over the role of the SCO in Afghanistan, following the US and ISAF-planned withdrawal by 2014, reflect this focus on regional identity construction and policy-making, rather than anti-NATO and anti-Western posturing and balancing. The SCO has suggested that Afghanistan should be addressed within a regional orbit, and that the SCO as a regionally-focused actor should play a role to this end. As noted by the Chinese Foreign Ministry Spokesman Liu Weimin,

Afghanistan borders others SCO members. The country's development will be closely linked to security and stability in the region. The fact that Afghanistan has become an observer member of the SCO will speed up security and cooperation (CNTV, 2012).

In 2009, the SCO hosted a conference on Afghanistan and in 2012 granted Afghanistan observer status within the organization. This further indicates that the issue of Afghanistan and the SCO's response to it should be read primarily as part of the SCO's regional remit, rather than as an attempt to build an anti-Western in-group.

\footnotetext{
${ }^{19}$ The 2009 SCO summit declaration noted that "the current situation in the global economic and financial sector points to the need to increase cooperation of the international community in the field of controlling and managing international finances, making joint efforts to prevent the growth and spread of financial crisis risks, maintaining economic stability" (Yekaterinburg Declaration of the Heads of the Member States of the Shanghai Cooperation Organization, 2009). 
Hence, elements of the SCO's geopolitical discourse emphasize that its central focus is on its Self, and specifically addressing the manifest security challenges within the Eurasian region, rather than countering West. However, the West is often framed within this discourse as an indirect Other, threatening to undermine the capacity of the SCO to focus on its Self, by interfering in Eurasia and restricting its capacity to develop regional norms and practices in response to regional challenges.

Making sense of the Other: the West's role in world and the protection of the regional from the global

In connection with the strands that promote itself as a self-referential regional actor, a key feature of the SCO's geopolitical discourse is the significance of local norms and the need to recognize and accept that the international system is made up of different normative contexts. In accordance with its promotion of the principle of non-interference in domestic affairs and a multipolar world, the SCO advocates a greater place for regional diversity of norms within the international system. It is argued that in Eurasia, it should be the SCO member states setting the norms of behavior as the actors with the most knowledge, experience and resources to do so. In this way, the 2011 Astana summit declaration notes that by taking a "path towards deepening good-neighborly, friendly and partner relations in the region" with the formation of SCO. Hence, it has "set a good example for the international community in the cause of achieving pragmatic and important result in the field of common development" (Astana Declaration of the 10th Anniversary of the Shanghai Cooperation Organization, 2011).

Within this recognition that multiple norms exist in the international system, the member states of the SCO consider that certain particular norms and values should form the basis of international relations. Whilst certain declarations and statements issued by the SCO contain criticism of the behavior of the West, and US in particular, these are also usually framed according to the commonly perceived normative standpoint developed within the SCO in-group. The common values and norms which underpin the SCO are termed the "Shanghai spirit", which puts the principle of non-interference in domestic affairs at the heart of the SCO. In connection with its emphasis on protecting the region from outside interference, the SCO champions the principles underlying the "Shanghai spirit" at an international level. Thus it advocates the centrality of "Westphalian" principles - as opposed to the post-Westphalian - of 
international relations that places state sovereignty and territorial integrity as the cornerstones of the international system. ${ }^{20}$

The SCO's declarations on international affairs and geopolitics thus, for the most part, reflect the views and values articulated within other aspects of the SCO. In this way, the membership of the SCO would prefer to see some of their commonly held values and positions at the center of the international system, in place of or alongside what its elites perceive as certain "Western" inspired norms. In this respect, Shaimergenov and Tusupbaeva declare that,

when analyzing the results of the Organization's summits, as well as statements made in the format of bilateral meetings of the member state leaders, the following program theses can be seen in them: the absence of any intention to build another military bloc; the striving to reduce unilateralism in international relations; the rejection of a hegemonic policy; and non-acceptance of unipolarity (Shaimergenov and Tusupbaeva, 2006).

In turn however, because many of the norms that the West promotes globally appear to clash with the norms that have been developed within the SCO, the West is often presented as harmful to the stability and security of this in-group (Ambrosio, 2009). Whereas most political actors in the West argue that it is the duty of national governments to protect human security across the world, and this duty can override the principle of state sovereignty, the member states of the SCO often express reservations about this position and emphasize that within the aim of promoting stability in global security that the principle of state sovereignty remains paramount. For example, in 2011 the "[SCO] heads of state noted that internal conflicts and crises must be resolved solely through peaceful means, through a political dialogue, whereas the international community must act in the direction of facilitating the processes of national reconciliation on the basis of strict observance of the international law, full respect for independence, sovereignty and territorial integrity, as well as upholding the principle of non-interference in internal affairs of all states" (Astana Declaration of the 10th Anniversary of the Shanghai Cooperation Organization, 2011).

The perceived need to assert this perspective strongly, especially with regard to Western actions in Eurasia, grew after the period of the "color revolutions" in the mid-2000s, which were interpreted by the leaderships of the SCO members as a threat to their regimes and regional

\footnotetext{
${ }^{20}$ The SCO Summit declaration (2006) stated that the "SCO owes its smooth growth to its consistent adherence to the "Shanghai Spirit" of "mutual trust, mutual benefit, equality, consultation, respect for multi-civilizations and pursuit of common development". This spirit is the underlying philosophy and the most important code of conduct of SCO. It enriches the theory and practice of contemporary international relations and embodies the shared aspiration of the international community for realizing democracy in international relations. The "Shanghai Spirit" is therefore of critical importance to the international community's pursuit of a new and non-confrontational model of international relations, a model that calls for discarding the Cold War mentality and transcending ideological differences". 
stability (Aris, 2011; Wilson, 2010; Allison, 2008; Ambrosio, 2008). This attitude was hardened by the widespread perception within Eurasia that Western actors, and specifically US government-supported NGOs, actively worked to provoke these "color revolutions" (Ortmann and Heathershaw, 2012; Wilson, 2010). Against this background, Western promotion of the need to override national sovereignty to the end of protecting individuals is largely read as a way of justifying actions sponsoring regime change to the advantage of Western governments.

At an international level, NATO's intervention in Kosovo in 1999 and the US-led coalition's military operation in Iraq in 2003 were perceived by the leaderships of the SCO's member states as undermining the prevailing norms of practice in international relations and generated significant misgivings about the changing normative landscape in the international system. ${ }^{21}$ The two side's reaction to the Arab Spring has further highlighted this normative difference. The SCO and its member states, particularly Russia and China, have continued to support the principle of non-interference in the Middle East and have been criticized by the West for doing so. As noted in the 2011 Astana summit declaration, "they [the SCO] oppose armed intervention or forced "regime change" and disapprove of unilateral sanctions" (Astana Declaration of the 10th Anniversary of the Shanghai Cooperation Organisation, 2011). Similarly on the question of Iran and nuclear proliferation, the SCO's promotion of the benefits of multipolarity are evident within the continued advocacy of the central role of the United Nations (UN) in standing against what is perceived as an aggressive and confrontational policy of the US. At the Beijing summit in 2012 it was outlined that the SCO

regard any attempt to resolve the Iranian issue by force is unacceptable as such attempts will produce unpredictable and serious consequences threatening the stability of the region and the world... They support the P5 plus one and Iran in opening sustainable dialogue process and they support efforts to find political and diplomatic solution to the Iranian nuclear issue through dialogue (Declaration of the Heads of State of the Member States of the Shanghai Cooperation Organization on Building a Region of Lasting Peace and Common Prosperity, 2012).

Thus, in international affairs the SCO and the West often emerge on different sides of global debates, particularly on issues of security and the role of the international community and international actors in local affairs. Within these geopolitical discourses, the West is

\footnotetext{
${ }^{21}$ For a detailed account of the member states' and the SCO's interpretation of the "colour revolutions" as an extra-regionally inspired threat to prevailing regional norms and regime security see (Ambrosio, 2009, pp.166-7). 
depicted, if not as an antagonistic Other, then as a very different Other, with little similarity to the SCO in-group.

Furthermore, within such geopolitical discourses, the image of the West is at times also conflated with a hegemonic "global" discourse. This "global" discourse is seen as laying down the norms of behavior for the international system, and is seen as opposing the norms advocated by the SCO. The leaderships of the SCO's member states, especially Russia and China, view the West as applying double standards in their expectations of them, compared to their own behavior. At the SCO annual summit in 2006, it was stated that

it [SCO] discards "double standards" .... Diversity of cultures and model of development must be respected and upheld. Differences in cultural traditions, political and social systems, values and model of development formed in the course of history should not be taken as pretexts to interfere in other countries' internal affairs. Model of social development should not be "exported" (Declaration on the Fifth Anniversary of the Shanghai Cooperation Organization, 2006).

In the same context, the SCO member states, especially Russia and China, have been critical of many Western states' recognition of Kosovo's unilateral declaration of independence from Serbia in February 2008, and none of its members have since recognized its independent status. Here again, the principle of non-interference in domestic affairs is promoted as the bedrock of the international system. In response to certain Western discourses advocating active involvement in the development of democratic systems and practices in other states, the former Secretary-General of the SCO Secretariat stated that "the process of democratic reforms is an internal business of each state and it is not possible to introduce these reforms from outside" (Zhang, 2006).

The SCO's elites view a combination of globalization and the aggressive promotion of Western values as threatening the capacity of states with a specific culture and values to maintain their unique historical identity. Concerns have particularly been raised about the West's use of soft power and primarily the internet and media. Two Tajik analysts argue that "until recently it was believed that security threats were limited to armed aggression. Today everything has changed: subversive information is spread through the Internet and there is information on "the ancient and unique culture" of this or that nation designed to fan nationalism" (Dodikhudoev and Niyatbekov, 2009). A common declaration at the 2010 SCO summit noted that "information security is closely linked with ensuring the state sovereignty, 
national security, social and economic stability and interests of citizens. All countries have the right, in accordance with their internal realities and on the legal basis, to operate the Internet, while enhancing cooperation in the spirit of equality and mutual respect" (Declaration of the Tenth Meeting of the Council of the Heads of the Member States of the Shanghai Cooperation Organization, 2010). This is again linked to the reaction of Eurasian elites to the "color revolutions" and the subsequent widening of the scope of the SCO's focus on state and regime security from the "three evils" to a much wider array of dynamics and trends. In relation to the SCO's depiction of the West, it has been influenced by the view that the West actively seeks to manipulate domestic political developments via the use of so called "political technologies", such as NGOs and activist websites.

Hence, at an international level, the SCO's geopolitical discourses are often framed in counterpoint to what is considered the Western-driven macro-discourse that pervades the current international system. These juxtapositions center on what the SCO discourse outlines as the attempts by the West to universalize their own values and sense of Self. This is often contrasted with the SCO's discourse that emphasizes the importance of the diversity of identity and values in the international system, and the right to protect this regional identity and its prevailing norms and practices from outside interference.

\section{Making sense of the Other: the West's role in Eurasia}

In accordance with the SCO's geopolitical stance on wider international affairs, the perceived role of the West in the SCO's own region has caused considerable tension and had a negative impact on the way in which the SCO perceives its relationship with the West. In connection with its activities within Eurasia, the SCO presents the West largely as an antagonistic Other, and as an agent advocating norms and practice that undermine the common positions and views established among the SCO in-group.

A key issue is the view that the West does not take into account the prevailing security or political context within Eurasia. In this respect, a Chinese official states that "certain Western countries, without taking into account concrete specific features of Central Asian states, consider 'democratic transformations' to be the main aim of their relations with the region, and even encourage 'color revolutions' in an attempt to broaden their political and military influence, which leads to greater instability in the region"” (Cited in Portyakov, 2008, p.162).

The leaderships of the SCO's member states consider that within the existing Westerninspired normative landscape there is no room for recognition of regional identity and values. 
Instead, the Western inspired model of liberal-democracy is pushed upon them regardless of circumstances. The former Secretary-General of the SCO highlighted this viewpoint, stating that,

democracy is a good thing, but its exercise in practice depends on the concrete situation on the ground in each region and each country. It is unacceptable to apply absolutely the same approach everywhere and inadmissible to transplant democracy by force, thus bestowing a doubtful benefit upon someone (Zhang, 2005).

Against this background, the member states' regimes consider the SCO as an important supporter of their domestic security policies, which attract criticism in the West. In this way, not only is the West presented as a negative Other, but the Self is presented as a necessary ingroup in order to protect the domestic interests of its member-states. The principle of nonintervention in domestic affairs underpins the faith of its member states that the SCO as an ingroup is a reliable mechanism in defense of their regimes. Ambrosio $(2009$, p. 174) argues that "a key component of the [SCO] defense of diversity is the argument that it is illegitimate for outsiders to 'impose' their version of democracy on anyone else". On this basis, the SCO is recognized as a mechanism for creating a preferable normative environment, in which the principle of non-interference in domestic affairs remains paramount. Thus, the SCO attempts to promote its intra-organizational norms and perceptions in its geopolitical discourse, with the aim of ensuring sufficient space for the Central Asian Republics to pursue their domestic security policies without the prospect of Western intervention and condemnation (Allison, 2008, pp. 186-8).

In this respect, the events of the "color revolutions" and Western reaction to the Andijan incident in 2005, had a significant impact on the interpretations of regional officials and analysts about the Western vision for the region. Following condemnation by the Western community of the Uzbek government for suppressing an uprising within is Andijan province, SCO included the following paragraph in its annual common declaration, which stated,

Taking into account the completion of the active combat phase of the antiterrorist operation in Afghanistan, the SCO member-states consider it necessary that the relevant members of the antiterrorist coalition take a decision on the deadlines for the temporary use of the abovementioned infrastructure facilities and military presence on the territory 
of the SCO member-states (Declaration of Heads of Member States of Shanghai Cooperation Organization, 2005)

This was interpreted as a direct message of communication to the West not to interfere in the SCO member-states' domestic affairs, and hence was expressed along a clear antagonistic SelfOther dynamic, whereby the Other violated the identity of the Self by trying to interfere within the in-group of the SCO member-states. This perspective comes against the background of increasing discomfort with the, potentially long-term, presence of US military bases in the region, which are viewed by Moscow and Beijing as a threat to both their security and influence in the region (Cooley, 2012; Deyermond, 2009). After endorsing the establishment of these bases, as part of the 2001 US led operation to remove the Taliban from power in Afghanistan and destroy Al-Qaeda, both Russia and China have become increasingly concerned about the continued US military presence in Eurasia following the completion of the initial operation in Afghanistan.

A challenge to the coherence of the SCO's principle of non-interference occurred as a result of Russia's actions and military posturing in the Russia-Georgia war in 2008. Moscow requested the other member states come out in support of its military action in Georgia, even though this appeared to be in contradiction with the principle of non-interference in domestic affairs (Swanstrom, 2008). Hence, the other members of the SCO were faced with a difficult situation, whereby they were being asked to undermine the primary principle of the organization because "one of its members' exercised the same 'double standards', for which it criticizes the West" (Aris, 2011, p. 145). In a rather pragmatic response, the SCO sought to sweep this issue under the carpet by not issuing a statement of support, but outlining in its 2008 Summit declaration that it acknowledged Russia's key role in maintaining peace in this region. The statement also reaffirmed its commitment to its non-interference doctrine. In addition, no other SCO member followed Russia in recognizing South Ossetia and Abkhazia as sovereign states.

The SCO has sought to reassert the centrality of "non-interference" within the SCO's geopolitical identity in the wake of the Russian-Georgia war, and indeed the legacy of this challenge to its geopolitical credibility was to some degree evident when these principles were articulated again during the Osh riots in Kyrgyzstan in 2010 (Aris, 2011, p. 471). In spite of a request for external assistance from the President of the interim Kyrgyz government, the SCO choose not to intervene. An SCO statement outlined that "in the light of developments in the Kyrgyz Republic, Member States reaffirm the principled position of mutual support of state sovereignty, independence and territorial integrity", noting that "they [SCO] oppose the interference in the internal affairs of sovereign states, as well as actions that could cause 20 
tensions in the region, and support the resolution of any disagreements exclusively by political and diplomatic means, through dialogue and negotiation" (Declaration of the Tenth Meeting of the Council of the Heads of the Member States of the Shanghai Cooperation Organization, 2010).

However, in all likelihood, the decision not to intervene in Kyrgyzstan was the product of a variety of geopolitical considerations not directly associated to the principle of noninterference. An important factor was Russia's concern "about the true allegiances of the interim government once its power is consolidated" (Bond and Koch, 2010, p. 551). As was Tashkent's reluctance to play a role in bringing security to Osh in spite of its proximity to the Uzbek border and the suffering of the ethnic Uzbek minority in Osh, because "Uzbekistan's elite-level wariness of the Uzbek diaspora, as evidenced by the general reluctance to accept refugees and efforts to close the border as quickly as possible" (Bond and Koch, 2010, p. 555). Indeed, it has been argued that "the events [the Osh riots in June 2010] have in fact exposed significant divisions among member states" (Bond and Koch, 2010, p. 553) and illustrated that the SCO has "no capacity for rapid reaction to such events, and the individual responses of its member states would suggest it is unable to call upon the political will of its members to form a common force" (Aris, 2012, p.471).

Nonetheless, in line with its wider geopolitical narrative, as illustrated by the statement above, the SCO sought to frame its non-intervention in Osh as due to its well-stated position of non-interference in domestic affairs. The placing of the principle of non-interference at the heart of the SCO's geopolitical identity in itself applies certain limitations on its ability to serve as an effective regional security actor, at least in terms of responding to security crises. This is because "the 'non-intervention' principle that is used to define the SCO, and the position and role it plays as a security guarantor for state and regime security, make the normative landscape to intervene in domestic affairs very limited" (Aris, 2012, p.471). Thus, the SCO's emphasis on the principle of non-interference in domestic affairs as the cornerstone of its geopolitical identity seems to be driven by its members' leaderships' fear of active intervention by external actors in their domestic affairs. As well as a reaction against international condemnation and punishment for their domestic policies aimed at regime security.

The SCO's geopolitical discourse with regard to Eurasia constructs the West as an antagonistic Other. This depiction is informed by the SCO's negative reading of the West's role in global affairs. The West is considered to be an actor that seeks to universalize its own norms and undermine and breech what the SCO sees as crucial principles of sovereignty, noninterference in local (domestic or regional) affairs. As a consequence, it is also said to challenge 
the importance of local/regional contexts in regional and international governance. However, while at times, this is constructed as different interpretations of the principles of sovereignty and intervention in the international system, as soon as this touches on a regional issue, or a SCO member, then the West becomes a direct antagonistic Other, read as a threat to the Westphalian basis of its member states.

\section{Potential avenues for cooperation with the West}

Within its official geopolitical discourse, the SCO argues that the world is becoming increasingly multipolar and fluid in its makeup. The 2012 Beijing summit declarations states that "the heads of state noted the on-going complex changes in the international system since the beginning of the 21 st century, featuring an increasingly multi-polar landscape, stronger regional coordination, deepening globalization, closer interdependence between countries and a larger role for information technologies" (Declaration of the Heads of State of the Member States of the Shanghai Cooperation Organization on Building a Region of Lasting Peace and Common Prosperity, 2012). As part of this viewpoint, and in spite of the many antagonisms in its relationship with the West on other issues, the SCO suggests that both sides are experiencing similar types of threats or face similar sources of tension to their security governance. The same declaration outlined that "it is imperative for the international community to meet global challenges through effective and concerted actions". In this respect, it is acknowledged within the SCO's geopolitical discourse that cooperation with the West focused on specific issues is potentially possible and advantageous.

The most prominent area in which the SCO has depicted the West as an actor with a similar identity to itself has been the SCO's attempt to inscribe itself within the international coalition against terrorism or "War on Terror", as part of its concerns with the "three evils". To this end, the SCO emphasized the commonality between Eurasian regional challenges and international ones, and its contribution to international approaches for dealing with such challenges

SCO member states, recognizing the transnational nature of today's terrorism and being in the forefront of the fight against its practical manifestations, are following a course of mutual cooperation and vigorous participation in the efforts of the world community in the struggle against terrorism, in particular, in stopping its financing channels. In this matter they assign an important role to close collaboration between the law enforcement 
agencies and secret services, and also the defense agencies of the SCO member states (Moscow Declaration of Heads of Member States of Shanghai Cooperation Organization, 2003).

However, this geopolitical discourse is not one based on a simplistic identification of similarity and commonality with the West. The SCO's approach to tackling the "three evils" simultaneously likened itself to and distinguishes itself from the global "War on Terror". It focuses on the one hand on "coordinating their actions with the US in combating international terrorism". While, at the same time continuing to "act according to their own programs and in their own interests, closely linking this struggle with counteraction to separatism and Islamic extremism" (Lukin, 2007, p.142). Nonetheless, its discourse on this issue signaled an effort by the SCO to define its identity as similar to, and in coordination with the West

Aside from the discourse on the war on terror, the issue of Afghanistan and wider regional security is another area identified as one of agreement and similarity, if not collaboration, between the SCO and the West. Notably, the SCO-hosted Conference on Afghanistan in 2009 included not only participants and representative from the region, but also international and Western actors - the first time US, European and NATO officials have been invited to a SCO gathering. Whilst, as noted above, the question of Afghanistan and regional security is often presented by the SCO as part of its regional policy and internal concerns, ${ }^{22}$ it is considered a global concern for the international community, and therefore that it could form part of a collaborative effort with the West. The 2012 Beijing summit declaration outlined that while "they are of the view that the national reconciliation process in Afghanistan should be Afghan-led and Afghan-owned", "the member states support the United Nations" leading role in coordinating the international efforts on the issue of Afghanistan (Declaration of the Heads of State of the Member States of the Shanghai Cooperation Organization on Building a Region of Lasting Peace and Common Prosperity, 2012). And as outlined in a SCO-Afghanistan joint statement following the 2009 conference, the SCO sets out an interest in collaboration with the West and wider international community, detailing an aim of "supporting the efforts of the Afghan Government and International Security Assistance Force in Afghanistan (ISAF) to improve law enforcement and combat the production and trafficking of narcotic drugs and curtailing the flow of precursors more effectively" (Statement by the Shanghai Cooperation Organization Member

\footnotetext{
${ }^{22}$ The 2011 Astana summit noted that "The member states stated that the unresolved situation in Afghanistan coupled with the continuing tension and confrontation in the country remains one of the key sources of threats to the regional security and stability" ("Joint Communiqué of meeting of the Council of the Heads of the Member States of the Shanghai Cooperation Organisation commemorating the 10th anniversary of the SCO”, June 15, 2011 [http://www.sectsco.org/EN/show.asp?id=293] accessed July 23, 2012. 
States and the Islamic Republic of Afghanistan on combating terrorism, illicit drug trafficking and organized crime, 2012). The SCO is particularly interested in collaboration on counternarcotics programs and operations as this is considered a major security challenge to several of its member states. However, the lack of reciprocation from NATO, which deems this issue as of a lower priority, has caused frustration among its members.

Furthermore, as it becomes more focused on an outward geopolitical role within international affairs, the SCO's geopolitical discourse is increasingly moving beyond a Self-Other dynamic based on the West, and towards a focus on other actors within international relations. As part of the SCO's geopolitical discourse that asserts that the international system is increasingly multipolar and interdependent, the SCO has highlighted the need for it to build up a broader coalition or in-group with other global and regional players. This has manifested itself in establishing diplomatic connections and partnerships with other multilateral institutions and structures, as seen in the signing of the cooperation agreement between the SCO and the UN in December 2009 (Joint Declaration on SCO/UN Secretariat Cooperation, 2010). The SCO has established agreements and partner links with the Commonwealth of Independent States (CIS), Collective Security Treaty Organization (CSTO), Eurasian Economic Community (EurAsEC), ASEAN, Economic and Social Commission for Asia and the Pacific (ESCAP) and Economic Cooperation Organization (ECO). Indeed as noted in the Astana summit declaration in 2011:

The heads of state note with satisfaction that in the past 10 years since the founding of the SCO, the Organization has become an important element of the fledgling network of multilateral association in the Asia Pacific region (Astana Declaration of the 10th Anniversary of the Shanghai Cooperation Organization, 2011).

This approach is akin to the concept of network diplomacy, and is centered on a greater flexibility and pragmatism than is allowed for in traditional fixed forms of geopolitical coalitions and in which the Self-Other dynamic is highly malleable. These partnerships and networks have become an increasingly key part of the SCO's geopolitical discourse, lessening the significance of its relationship with the West for defining its spatial and normative identity within the international system. As this process develops, it is likely that the centrality of the West to the SCO's geopolitical identity constructions will in fact decline further. This perhaps reflects a wider geopolitical reorientation of space and identities within the international system, in which viewing all aspects of geopolitics through the perspective of the West, as the hegemonic centerpoint, becomes outmoded, or at least not the only relevant vantage point. 
In spite of tensions over the norms that shape and drive contemporary international relations, and criticism of what it envisions as the West's antagonistic interference in Eurasia, the SCO's geopolitical discourse has also identified some areas of common interest and grounds for collaboration between the Self and the Other. This includes the potential for the creation of an ad-hoc temporary macro in-group with the West, on certain issues area and certain spaces. In addition, the SCO is actively seeking to develop relationships with a range of other nonWestern actors, and these alternative Self-Other dynamics are increasingly becoming more important to the SCO. In this way, its definition of itself in relation to the West will become a less significant factor, and will open space for it to develop a wider range of geopolitical space for its relationship with other actors, and in its constructions of its own "geopolitical imaginary".

\section{Conclusion}

As the tracing of its geopolitical discourse has demonstrated, the SCO's identity is not constructed on the basis of a single identity and discourse between the Self (the SCO) and the Other (the West). While acknowledging that the SCO is far from a coherent amalgamation of its member states' views on the world and faces a number of practical challenges in enacting its rhetoric, this article has argued that the SCO's geopolitical discourse and constructs of its Self/Other relations are composed of three broad types: the discourse on the Self from within (collective identity); the Other as similar/different; and the Other as an opposite.

From this perspective, it is asserted that contrary to many depictions of the SCO as centered on a binary identity construction of countering the West, multi-faceted and fluid identity constructions are evident within the SCO's geopolitical discourses. The nature of the Self-Other dynamic vis-à-vis the West varies across spatial, issue and temporal contexts. Thus, on many issues and within many spaces, the SCO's geopolitical discourse on both international and regional affairs is indeed built upon a Self-Other dynamic that contrasts their common positions on certain international issues against those of the West. The most antagonistic interpretation of the West as an Other emerges in contexts in which the West is seen as directly challenging the collective identity of the SCO as an in-group, in terms of interference in the Eurasian space towards the end of influencing, or altering, internal affairs. A slightly more benign depiction of the West as a different Other can be found on issues within the global space that do not directly touch on the SCO's identity as an in-group, in particular on issues that most 
obviously point to a degree of common interest such as in the case of counter narcotics programs in Afghanistan.

However, on other issues in other contexts, the SCO's geopolitical discourse notes similarity to the West and is aimed at building a larger in-group between itself and the West, primarily with regard to international terrorism and the future stability of Afghanistan. On this basis, it is suggested that the SCO's geopolitical discourse on international/regional affairs functions to construct its identity as a limited in-group, which both rejects and seeks to work together with their perceived significant Other (the West).

Within this geopolitical imaginary, the SCO seeks to close, or limit, the space available to the West within what it considers its own regional jurisdiction and at the same time assert its ownership, and identity in terms, of the Eurasian space. Beyond the immediate Eurasian space, the SCO also seeks to close space to the West and open space for itself on certain issues of global norms and standards, but on other issues also seeks to open space for the West, and specifically for collaboration with the West, most notably over Afghanistan and the War on Terror.

As highlighted in the analytical framework section, there is a tendency to dismiss collective identity building in most non-Western regional organizations that is not based on juxtaposition to the West, as part of the Western-centric focus on a "traditional" geopolitical perspective. However, as argued above, collective identity building processes centered on regional concerns and considerations form a central part of the SCO's geopolitical discourse and identity building narratives. Therefore, the SCOs collective identity building and geopolitical discourses cannot be reduced to its relationship with an Other (i.e. the West). 


\section{References}

Abizadeh, Arash, "Does collective identity presuppose an Other? On the alleged incoherence of global solidarity", American Political Science Review, 99, 1: 45-60, 2005.

Acharya, Amitav and Barry Buzan, eds, Non-Western International Relations Theory: Persepctives on and beyond Asia. London and New York, Routledge, 2010.

Acharya, Amitav, "Dialogue and Discovery: In Search of International Relations Theories beyond the West”, Millennium - Journal of International Studies, 39, 3:619-637, 2011.

Acharya, Amitav, Constructing a Security Community in Southeast Asia: ASEAN and the Problem of Regional Order. New York and London: Routledge, 2001.

Adomeit, Hannes, "Russia as a 'Great Power' in World Affairs: Images and Reality", International Affairs, 71, 1: 35-68, 1995.

Agathangelou, Anna M. and Ling, L. H. M., Transforming world politics: from empire to multiple worlds. New York, Routledge, 2009.

Agnew, J., Geopolitics: Re-Visioning World Politics. London: Routledge, 2003.

Allison, Roy, "Virtual regionalism, regional structures and regime security in Central Asia", Central Asian Survey, 27, 2, 2008.

Allison, Roy, "Regionalism, Regional Structures and Security Management in Central Asia", International Affairs, 80, 3, 2004.

Ambrosio, Thomas, Authoritarian backlash: Russian resistance to democratization in the former Soviet Union. Farnham: Ashgate; 2009.

Ambrosio, Thomas, "Catching the 'Shanghai Spirit': How the Shanghai Cooperation Organization Promotes Authoritarian Norms in Central Asia", Europe-Asia Studies, 60, 8: 1321-1344, 2008.

Aris, Stephen, "The Response of the Shanghai Cooperation Organisation to the Crisis in Kyrgyzstan”, Civil Wars, 14, 3: 451-476, 2012

Aris, Stephen, Eurasian Regionalism: The Shanghai Cooperation Organisation. Basingstoke, Palgrave Macmillan, 2011.

Aris, Stephen, "Spreading the Shanghai Spirit: The Chinese Model of Regionalisation in PostSoviet Central Asia" in Emilian Kavalski, ed., China and the Global Politics of Regionalization. Ashgate, Farnham, 2009.

Aris Stephen, "Tackling the three evils: Shanghai Cooperation Organisation (SCO) - A regional response to non-traditional security challenges or an anti-Western bloc?", Europe-Asia Studies, 61, 5: 457-482, 2009.

Astana Declaration of the 10th Anniversary of the Shanghai Cooperation Organisation, June 27 
15, 2011 [http://www.sectsco.org/EN/show.asp?id=294], accessed July 15, 2012.

Bailes, Alyson and Pal Dunay, "The Shanghai Cooperation Organisation as a regional security institution" in Alyson Bailes, Pal Dunay, Pan Guang and Mikhail Troitskii, eds., The Shanghai Cooperation Organisation. Stockholm International Peace Research Institute, Policy Paper No. 17, 2007.

Barkawi, Tarak and Laffey, Mark, "The Postcolonial Moment in Security Studies", Review of International Studies, 32, 2: 329-352, 2007.

BBC, "China and Russia lead group talks focused on security", June 6, 2012.

Bilgin, Pinar, "Thinking Past "Western IR", Third World Quarterly, 29, 1: 5-23, 2008.

Bond, Andrew R. and Natalie R. Koch, "Interethnic Tensions in Kyrgyzstan: A Political Geographic Perspective", Eurasian Geography and Economics, 51, 4: 531-562, 2010.

Borodavkin, Aleksei (Interview in) "ShOS - organizatsiya partnerstva i mira", VIP-Premier Magazine, 11-12, 2008.

[http://www.vip-premier.ru/inside.php?action=statia\&id=6624\&pid=519], accessed 24 March 2009

Brownback, Sam, (speech entitled) "The Shanghai Cooperation Organisation: Is It Undermining US Interests In Central Asia?", US Senate Commission on Security and Cooperation Conference) September 26, 2006, cited in Heather Maher, "Central Asia: US Helsinki Commission concerned about SCO's influence", Eurasia Insight, October 1, 2006 [http://www.eurasianet.org/departments/insight/articles/pp100106.shtml] accessed April 10, 2008.

Buzan, Barry and Waever, Ole, "Macrosecuritisation and security constellations: reconsidering scale in securitisation theory", Review of International Studies 35, 2: 253-276, 2009

Campbell, David, Writing Security: United States Foreign Policy and the Politics of Identity. University of Minnesota Press, 1998.

Carroll, William E., "China in the Shanghai Cooperation Organization: Hegemony, MultiPolar Balance or Cooperation in Central Asia", International Journal of Humanities and Social Science, 1, 19: 1-8, 2011

Charter of the Shanghai Cooperation Organization, June 7, 2002.

"China welcomes Afghanistan as SCO observer," CNTV.cn, June 6, 2012 [http://english.cntv.cn/program/newsupdate/20120606/114687.shtml], accessed July 28, 2012.

Chung, Chien Peng, "China and the Institutionalisation of the Shanghai Cooperation Organisation", Problems of Post-Communism, 53, 5, 2006.

Cohen, Ariel, "The U.S. Challenge at the Shanghai Summit," The Heritage Foundation, August 13, 2006 [http://www.heritage.org/research/asiaandthepacific/h1961.cfm] acces July 21, 2012. 
Cooley, Alexander, Great games, local rules the new great power contest in Central Asia. New York; Oxford University Press, 2012.

Dalby Simon, "Recontextualising violence, power and nature: The next twenty years of critical geopolitics?”, Political Geography, 29, 5: 280-288, 2010a.

Dalby, Simon, "Critical Geopolitics and Security" in Peter J. Burgess ed., Handbook of new security studies. London: Routledge, $2010 \mathrm{~b}$.

Dalby, Simon, Imperialism, Domination, Culture: the Continued Relevance of Critical Geopolitics”, Geopolitics, 13, 3: 413-436, 2008.

Dalby, S., "Critical geopolitics: discourse, difference, and dissent", Environment and Planning D: Society and Space, 9, 3: 261-283, 1991.

Declaration of the Heads of State of the Member States of the Shanghai Cooperation Organization on Building a Region of Lasting Peace and Common Prosperity, June 7, 2012 [http://www.fmprc.gov.cn/eng/wjdt/2649/t939149.htm], accessed August 10, 2012.

Declaration of the Tenth Meeting of the Council of the Heads of the Member States of the Shanghai Cooperation Organization, June 11, 2010 [http://www.sectsco.org/EN/2010.asp], accessed July 25, 2012.

Declaration on the Fifth Anniversary of the Shanghai Cooperation Organization, June 15, 2006 [http://www.sectsco.org/EN/show.asp?id=94], accessed July 11, 2012.

Declaration of Heads of Member States of Shanghai Cooperation Organization, July 5, 2005 [http://www.chinadaily.com.cn/china/2006-06/12/content_614632.htm], access September 3, 2012.

Deyermond, Ruth, "Matrioshka hegemony? Multi-levelled hegemonic competition and security in post-Soviet Central Asia”, Review of International Studies, 35, 1: 151-173, 2009.

de Haas, Marcel, “The Shanghai Cooperation Organization's momentum towards a mature security alliance", Scientia Militaria, 36, 1, 2008.

Dodikhudoev, Khurshed and Vafo Niyatbekov, "Kitaiskii vektor vo vneshnei politike Tadzhikistana", Tsentral'naya Aziya i Kavkaz, 62, 2, 2009.

Diez, Thomas, "Europe's Others and the Return to Geopolitics," Review of International Studies, 17, 2:319-335

Diez, Thomas, "Constructing the Self and Changing Others: Reconsidering "Normative Power Europe”, Millennium: Journal of International Studies, 33, 3: 613-36, 2005.

Epstein, Charlotte, "Who speaks? Discourse, the subject and the study of identity in international politics", European Journal of International Relations, 17, 2: 327-350, 2011.

Ferguson, Chaka, "The Strategic Use of Soft Balancing: The Normative Dimensions of the Chinese-Russian 'Strategic Partnership"”, Journal of Strategic Studies, 35, 2, 2012. 
Fiacconi, Giorgio, "China, Russia and Central Asian countries of SCO want more involvement in Afghanistan," Times of Central Asia, 8 June, 2012 [http://www.stratfor.com/othervoices/china-russia-and-central-asian-countries-sco-want-more-involvement-afghanistan], accessed September 12, 2012.

Frolenkov, Vitalii, "China and the SCO Member Countries of Central Asia: Cooperation Over Energy”, Far Eastern Affairs, 36, 2, 2008.

Germanovich, Gene, "The Shanghai Cooperation Organisation: A Threat to American Interests in Central Asia?", China and Eurasia Forum Quarterly, 6, 1, 2008.

Glassman, Jim, "On the borders of Southeast Asia: Cold War geography and the construction of the other", Political Geography, 24, 7:784-807, 2005.

Halpin, Tony, "Rival to Nato' Begins First Military Exercise", The Times Online, August 6, 2007.

Hanova, Selbi, "Perspectives on the SCO: Images and Discourses", China and Eurasia Forum Quarterly, 7, 3, 2009.

Hansen, Lene, Security as Practice: Discourse Analysis and the Bosnian War. London and New York: Routledge, 2006.

Heather Maher, H., 'Central Asia: US Helsinki Commission concerned about SCO's influence', Eurasia Insight, October 1, 2006

[http://www.eurasianet.org/departments/insight/articles/pp100106.shtml]accessed Nov 26, 2006.

Heathershaw, John and Megoran, Nick, "Contesting danger: a new agenda for policy and scholarship on Central Asia”, International Affairs, 87; 589-612, 2011.

Heathershaw, John, "Worlds apart: the making and remaking of geopolitical space in the USUzbekistani strategic partnership”, Central Asian Survey, 26,1;123-140, 2007.

Herschinger, Eva, "Hell Is the Other': Conceptualising Hegemony and Identity through Discourse Theory", Millennium 41, 1: 65-90, 2012.

Hobson, John, The Eurocentric Conception of World Politics: Western International Theory, 1760-2010. Cambridge: Cambridge University Press, 2012.

Hobson, John, "Is Critical Theory Always For the White West and For Western Imperialism? Beyond Westphalian, Towards a Post-Racist International Relations", Review of International Studies, 33: 91-116, 2007.

Honneland, Gei, "Identity Formation in the Barents Euro-Arctic Region", Cooperation and Conflict, 33,3: 277-297, 1998.

Hopf, Ted, Social Construction of Foreign Policy: Identities and Foreign Policies, Moscow, 1955 and 1999. Cornell University Press, 2002. 
Hutchings, Kimberly, "Dialogue Between Whom? The Role of the West- Non-West Distinction in Promoting Global Dialogue in IR", Millennium - Journal of International Studies, 39, 3: 639-647, 2011 .

Joint Declaration on SCO/UN Secretariat Cooperation, April 8, 2010 [http://www.sectsco.org/EN/show.asp?id=198] accessed July 24, 2012.

Joint Communiqué of Meeting of the Council of the Heads of the Member States of the Shanghai Cooperation Organisation, June 16, 2006 [http://www.sectsco.org/EN/show.asp?id=95], accessed July 11, 2012.

Kaplan David C. and Jouni Hakly, eds., Boundaries and Place: European Borderlands in Geographical Context. Rowman and Littlefield, 2002.

Kilner, James, "Western oil firms pay Kazakhstan's oil field investment bill”, The Telegraph, May 28, 2012.

Krasner, Stephen D., Sovereignty: Organized Hypocrisy. Princeton, NJ: Princeton University Press 1999.

Lanteigne, Marc, “In Medias Res': The Development of the Shanghai Co-operation Organization as a Security Community”, Pacific Affairs 79, 4: 605-622, 2006/2007.

Lukin, Aleksandr, "The Shanghai Cooperation Organisation: What Next?", Russia in Global Affairs, 2, 2007.

Mackinder, H. J., "The Geographical Pivot of History”, Geographical Journal, 23, 4:421-437, 1904.

Maksutov, Ruslan, The Shanghai Cooperation Organisation: A Central Asian Perspective. SIPRI Project Paper, August, 2006.

Mamadouh, Virginie and Gertjan Dijink, "Geopolitics, International Relations and Political Geography: the Politics of Geopolitical Discourse”, Geopolitics, 11, 3:349-366, 2006.

Marketos, Thrassy, "Eastern Caspian Sea Energy Geopolitics: A Litmus Test of the US Russia - China for the Geostrategic Control of Eurasia”, Caucasian Review of International Affairs, 3, 1, 2009a.

Marketos, Thrassy, China's energy geopolitics: the Shanghai Cooperation Organisation and Central Asia. Abingdon: Routledge, 2009b.

Matusov, Artyom, "Energy Cooperation in the SCO: Club or Gathering?", China and Eurasia Forum Quarterly, 5, 3: 83-99, 2007.

McDermott, Roger, "Kyrgyz Instability Presents Challenges for Russia, China and the SCO", Eurasia Daily Monitor, 7, 86 May 4, 2010.

Melvin, Neil, Eurasian security arrangements face reality check after Kyrgyzstan crisis. Stockholm International Peace Research Institute Essay, July/August 2010. 
Mitchell, Katharyne, "Ungoverned space: Global Security and the geopolitics of broken windows”, Political Geography, 29, 5:289-297, 2010.

Megoran, Nick, "Revisiting the 'pivot': the influence of Halford Mackinder on analysis of Uzbekistan's international relations”, The Geographical Journal, 170, 4; 347-358, 2004.

Morozov, Viatcheslav and Bahar Rumelili, "The External Constitution of European Identity: Russia and Turkey as Europe-Makers", Cooperation and Conflict, 47, 1:28-48.

Morozov, Yurii, “Mirovoi krizis i geopoliticheskaya situatsiya v tsentral'noaziatskom regione: aktual'nye voprosy strategii razvitiya ShOS v XXI veke”, Problemy Dal'nego Vostoka, 3, 2009.

Moscow Declaration of Heads of Member States of Shanghai Cooperation Organization, May $29,2003 \quad$ [http://archive.kremlin.ru/eng/events/articles/2003/05/162318/162321.shtml], accessed November 11, 2008.

Mouffe, Chantal, The Democratic Paradox. London: Verso, 2000.

Neumann, Iver, "Russia as a great power, 1815-2007", Journal of International Relations and Development, 11: 128-151, 2008.

Neumann Iver, Russia and the Idea of Europe: a study in Identity and International Relations. London and New York: Routledge, 1996.

Neumann Iver, Uses of the Other: the 'East' in European Identity Formation. Minneapolis, MN: University of Minnesota, 1999.

Naarajärvi, Teemu, "China, Russia and the Shanghai Cooperation Organisation: blessing or curse for new regionalism in Central Asia?”, Asia Europe Journal, 10, 2: 113-126, 2012.

Ortmann, Stefanie and Heathershaw, John, "Conspiracy Theories in the Post-Soviet Space", The Russian Review, 71: 551-564, 2012.

Ortmann, Stephanie, Re-imagining Westphalia: identity in IR and the construction of the Russian State. London School of Economics and Political Science. PhD Thesis, 2008.

Ó Tuathail, G., and J. Agnew, "Geopolitics and discourse: practical geopolitical reasoning in American foreign policy”, Political Geography, 11, 2: 190-204, 1992.

Ó Tuathail, G., Critical geopolitics: The politics of writing global space. Minneapolis: University of Minnesota Press, 1996.

Paasi, A., "Texts and contexts in the globalizing academic marketplace: comments on the debate on geopolitical remote sensing", Eurasian Geography and Economics, 47: 216-220, 2006.

Pan, Guang, "China in the Shanghai Cooperation Organisation", in Gungwu Wang and Yongnian Zheng, eds., China and the new international order. eds. Milton Park, Abingdon, Oxon; Routledge, 2008.

Pannell, Clifton W., "China Gazes West: Xinjiang’s Growing Rendezvous with Central Asia”, 
Eurasian Geography and Economics, 52, 1: 105-118, 2011.

Popescu, Gabriel, "The conflicting logics of cross-border reterritorialization: Geopolitics of Euroregions in Eastern Europe”, Political Geography, 27, 4:418-438, 2008.

Portyakov, Vladimir, "Konferentsiya po problemam Tsentral'noi Azii i Shankhaiskoi organizatsii sotrudnichestva", Problemy Dal'nego Vostoka, 1, 2008.

Portyakov, Vladimir, "The Shanghai Cooperation Organization: Achievements, Problems, Prospects", Far Eastern Affairs, 35, 4: 1-9, 2007.

Prozorov, Sergei, "The narratives of exclusion and self-exclusion in the Russian conflict discourse on EU-Russian Relations”, Political Geography, 26, 3:309-329, 2007.

Prozorov, Sergei, "The other as past and present: beyond the logic of 'temporal othering' in IR theory", Review of International Studies, 37, 3:1273-1293, 2012.

Putin, Vladimir, SCO - a New Model of Successful International Cooperation, June 14, 2006 [http://archive.kremlin.ru/eng/speeches/2006/06/14/0014_type104017_107007.shtml], accessed March 11, 2009.

Robinson, Jenny., "Political geography in a postcolonial context", Political Geography, 22, 6: 647-651, 2003.

Rumelili, Bahara "Constructing Identity and Relating to Difference: Understanding the EU's Mode of Differentiation”, Review of International Studies, 30, 2004.

Sengupta, Anita, Heartlands of Eurasia: The Geopolitics of Political Space. Plymouth: Lexington, 2009.

Shaimergenov, Timur and Gul'nar Tusupbaeva, "Rol' ShOS v formirovanii tsentral'noaziatskoi sredy bezopasnosti: geopoliticheskie aspekty", Tsentral'naya Aziya $i$ Kavkaz, 44, 2, 2006.

Shanghai Convention on Combating Terrorism, Separatism and Extremism, June 15, 2001.

Sheives, Kevin, "China Turns West: Beijing's Contemporary Strategy towards Central Asia”, Pacific Affairs, 79, 2: 205-224, 2006.

Sidaway, J. D., "The geography of political geography", in K. Cox, M. Low and J. Robinson, eds., The Sage handbook of political geography. London: Sage, 2008.

Sky News, "Russia Sanctions 'Being Considered'”, August 29, 2008.

Statement by the Shanghai Cooperation Organization Member States and the Islamic Republic of Afghanistan on combating terrorism, illicit drug trafficking and organized crime, March 27, 2009 [http://www.sectsco.org/EN/2009.asp], accessed July 24, 2012.

Suzuki, Shogo, “The importance of 'Othering' in China's national identity: Sino-Japanese relations as a stage of identity conflicts”, The Pacific Review, 20, 1: 23-47, 2007. 
Swanstrom, Niklas, "Shanghai Cooperation Organization and the Aftermath of the Russian Invasion of Georgia", China and Eurasia Forum Quarterly, 6, 3, 2008.

Tickner, Arlene, "Seeing IR Differently: Notes from the Third World", Millennium - Journal of International Studies, 32, 3: 295-324, 2003.

Tickner, Arlene and Ole Waever, eds., International Relations Scholarship around the World. London and New York: Routledge, 2009.

Toal, Gerard, "Re-asserting the regional: political geography and geopolitics in world thinly known”, Political Geography, 22, 6: 653-655, 2003.

Treaty on Long-Term Good-Neighbourliness, Friendship and Cooperation Between the Member States of the Shanghai Cooperation Organization, August 16, 2007.

Troitskii, Mikhail, "A Russian perspective on the Shanghai Cooperation Organisation", in Alyson Bailes, Pal Dunay, Pan Guang and Mikhail Troitskii, eds., The Shanghai Cooperation Organisation. Stockholm International Peace Research Institute, Policy Paper No. 17, 2007.

Tsygankov, Andrei, "Vladimir Putin's Vision of Russia as a Normal Great Power", Post-Soviet Affairs, 21, 2: 132-158, 2005.

Waver Ole, "Securitization and desecuritization", in Lipschutz R ed., On Security. New York: Columbia University Press, 1995.

Weitz, Richard, "New Kazakhstan-US Energy Partnership Plan Adopted”, Eurasia Daily Monitor 9, 201, November 2, 2012.

Weitz, Richard, “What's Happened to the SCO?”, The Diplomat, May 17, 2010.

Wendt, Alexander, "Anarchy is what states make of it: the social construction of power politics," International Organization, 46, 2: 391-425, 1992.

Wilhelmsen, Julie and Geir Flikke, "Russian-Chinese Convergence and Central Asia", Journal of Geopolitics, 4, 16: 865-901, 2011.

Wilson, Jeanne L., "Coloured Revolutions: The View from Moscow and Beijing", in David Lane and Stephen White eds., Rethinking the 'coloured revolutions'. London: Routledge, 2010.

Wishnick, Elizabeth, Russia, China, and the U.S. in Central Asia: Competition and Cooperation in the Shadow of the Georgian Crisis. Strategic Studies Institute, U.S. Army War College, February 2009.

Xinhuanet, "China offers 10-bln-USD SCO loan", Xinhuanet.com, June 7, 2012 [http://news.xinhuanet.com/english/china/2012-06/07/c_131637089.htm], accessed July 31, 2012.

Yekaterinburg Declaration of the Heads of the Member States of the Shanghai Cooperation Organization, June 15, 2009 [http://www.sectsco.org/EN/show.asp?id=87], accessed September 12, 2009. 
Zhang, Deguang, "Interv'yu kitaiskomu zhurnalu 'ChzhunKhuaintsai",, May 25, 2005 in Vyzovy i bozmozhnosti. Shankhaiskaya Organizatsiya Sotrudnichestva, 2006.

Zhang, Deguang, interview in Ministry for Foreign Affairs of the Russian Federation, Diplomaticheskii Vestnik, June 6, 2005.

Zhao, Huasheng, "Prospects of the Shanghai Cooperation Organisation," China International Studies, 3, 2006. 